\title{
MANAJEMEN PENDIDIKAN BERORIENTASI MASA DEPAN
}

\section{Ketut Soter}

Institut Agama Hindu Negeri Tampung Penyang Palangkaraya

bawiayahfda@gmail.com

\begin{abstract}
Riwayat Jurnal
Artikel diterima :-

Artikel direvisi : :

Artikel disetujui : -
\end{abstract}

\begin{abstract}
Abstrak
Perkembangan sains dan teknologi saat ini juga mempercepat laju perkembangan ekonomi dan industri, yang memiliki implikasi penting bagi dunia pendidikan. Salah satu dampak paling signifikan dari pertumbuhan dan perkembangan ekonomi adalah dampak kerja, baik dilihat dari kebutuhan masyarakat maupun kemampuan untuk menyediakan tenaga kerja. Masalah persiapan tenaga kerja yang ditemui di lapangan adalah rendahnya kualitas tenaga kerja, biasanya kondisi fisik, kualitas pendidikan, dan etika kerja sangat dominan dalam menentukan tenaga kerja. Hal ini penting diperhatikan untuk mewujudkan arahan Presiden Republik Indonesia dalam membangun pendidikan guna mempersiapkan generasi emas tahun 2045 yang dikhususkan, nasionalis, tangguh, mandiri dan memiliki keunggulan kompetitif di masa depan. Pendidikan adalah sektor yang sangat menentukan kualitas suatu bangsa. Keberhasilan pendidikan juga secara otomatis membawa sebuah bangsa. Mengoptimalkan dunia pendidikan, yang menekankan unsur-unsur pendidikan, penting: pelajar, pendidik, perangkat lunak, manajemen, sarana dan prasarana serta pemangku kepentingan. Aset yang dibutuhkan dalam pendidikan adalah sumber daya manusia yang berkualitas. Sumber daya berkualitas bisa berasal dari siswa, masyarakat, maupun pendidik. Setiap jenis pengetahuan termasuk pengetahuan manajemen memiliki fitur spesifik mengenai apa (ontologi), bagaimana (epistemologi) dan untuk apa (aksiologi) pengetahuan manajemen terstruktur. Ketiganya saling terkait satu sama lain (sistem). Ontologi sains yang berkaitan dengan epistemologi, dan epistemologi yang terkait dengan aksiologi dan sebagainya, tidak dapat dipisahkan dan harus saling terkait dan mendukung sebagai dasar. Berdasarkan dasar ontologi dan aksiologi, maka bagaimana cara mengembangkan pondasi epistemologis yang tepat. Masalah utama yang dihadapi oleh setiap epistemologi pada dasarnya adalah bagaimana mendapatkan pengetahuan yang benar dengan memperhatikan aspek ontologi dan aksiologi.
\end{abstract}

Kata kunci: Pendidikan, Manajemen.

I. PENDAHULUAN

Jurnal Bawi Ayah. Volume 9. Nomor 2. Oktober 2018

Perkembangan ilmu dan teknologi
dewasa ini turut mempercepat laju


perkembangan ekonomi dan industri, yang mempunyai implikasi penting terhadap dunia pendidikan. Salah satu dampak pertumbuhan dan perkembangan ekomomi yang paling nyata dirasakan yaitu menyangkut lapangan kerja, baik dilihat dari kebutuhan masyarakat maupun kemampuan dalam menyediakan atau menyiapkan tenaga kerja. Dalam hubungannya dengan masalah penyiapan tenaga kerja. Dalam hubungan dengan masalah penyiapan tenaga kerja, yang dihadapin di lapangan yaitu rendahnya mutu tenaga kerja, biasanya raviabel kondisi fisik, kualitas pendidikan, dan etos kerja sangat dominan dalam menentukan tenaga kerja.

Untuk merealisasikan arahan

Presiden Republik Indonesia tentang penguatan pendidikan guna mempersiapkan generasi emas tahun 2045 yang bertaqwa, nasionalis, tangguh, mandiri dan memiliki keunggulan bersaing secara global maka bidang pendidikan yang berkelanjutan berorientasi masa depan harus diwujudkan, salah satu hal sangat yang perlu diperhatikan. Pendidikan merupakan sektor sangat menentukan kualitas suatu bangsa. Kegagalan pendidikan berimplikasi pada gagalnya suatu bangsa, keberhasilan pendidikan juga secara otomatis membawa keberhasilan sebuah bangsa. Optimalisasi pada dunia pendidikan, hendaknya memperhatikan unsur pendidikan, yang diantaranya: peserta didik, pendidik, software, manajemen, sarana dan prasarana dan stake holder. Aset yang diperlukan dalam pendidikan adalah sumber daya manusia yang bekualitas. Sumber daya yang berkualitas dapat berupa dari siswa, masyarakat, maupun dari pendidik.

Pelaksanaan suatu pendidikan mempunyai fungsi, antara lain: inisiasi, inovasi, dan konservasi. Inisiasi merupakan fungsi pendidikan untuk memulai suatu perubahan. Inovasi merupakan wahana untuk mencapai perubahan. Konservasi berfungsi untuk menjaga nilai-nilai dasar. Oleh sebab itu, untuk memperbaiki kehidupan suatu bangsa, harus dimulai penataan dari segala aspek dalam pendidikan. Salah satu aspek yang dimaksud adalah manajemen pendidikan.Tujuan dari pendidikan yang diharapkan adalah menciptakan out come pendidikan yang berkualitas sesuai dengan harapan dari berbagai pihak. Dalam hal ini, manajemen pendidikan mempunyai peranan yang sangat penting. Manajemen yang bagus (good management) dalam dunia pendidikan di Indonesia sangat diharapkan oleh seluruh warga Indonesia.

Suatu manajemen pendidikan yang bagus dapat diciptakan dan dapat dilaksanakan oleh manajer pendidikan yang berkualitas, karena kedua hal tersebut harus saling suport. Manajer dalam dunia pendidikan salah satunya adalah guru dan dosen. Tugas guru dan dosen selain mengajar, juga menjadi seorang manajer pendidikan. Seorang guru dan dosen harus dapat merencanakan manajemen yang baik. Manajer pendidikan yang bagus adalah 
seseorang yang mau merencanakan manajemen pendidikan secara berkelanjutan serta bisa proyeksi dimasa yang akan datang.

Kenyataan yang ada sekarang adalah masih buruknya manajemen pendidikan yang ada. Buruknya manajemen pendidikan disebabkan oleh berbagai faktor. Para manajer pendidikan tidak mau merencanakan manajemen yang berkelanjutan dan menjadi proyeksi dimasa yang akan datang. Para manajer pendidikan hanya masih berorientasi pada acuan manajemen lama. Masih jarang sekali yang ingin merencanakan sesuatu yang baru. Hal ini dikarenakan para manajer pendidikan tidak mau mengambil resiko pada dirinya dan pada pendidikan. Dengan adanya pandangan yang selalu kebelakang maka manajemen tidak akan maju, tapi malah mengalami kemunduran.

Fakta menunjukan bahwa dulu Negara Malaysia banyak yang belajar di Indonesia, tapi sekarang kenyataannya pendidikan di Indonesia sudah tertinggal dari Negara Malaysia. Salah satu faktor utamanya adalah manajemen yang kurang siap menghadapi masa depan. Pada kesempatan ini, penulis akan memaparkan suatu manajemen pendidikan dimasa depan, guna mendapatkan hasil pendidikan yang diharapkan. Dalam rangka membantu meningkatkan mutu pendidikan, para pengelola pendidikan dituntut untuk memperkarya wawasan pengetahuan, kemampuan yang relewan dengan pekerjaanya.

\section{PEMBAHASAN}

\subsection{Pengertian Tentang Manajeman}

Manajemen sering diartikan sebagai ilmu, kiat dan profesi. Dikatakan sebagai ilmu oleh Luther Gulick karena manajemen dipandang sebagai suatu bidang pengetahuan yang secara sistematik berusaha memahami mengapa dan bagaimana orang bekerja sama. Dikatakan sebagai kiat oleh Follet karena manajemen menjapai sasaran melalui cara-cara dengan mengatur orang lain dalam menjalankan tugas. Dipandang sebagai profesi karena manajemen dilandasi oleh keahlian khusus untuk mencapai suatu prestasi manajer, dan para profesional dituntun oleh suatu kode etik.

Meskipun cenderung mengarah pada satu fokus tertentu, para ahli masih berbeda pandangan dalam mendifinisikan manajemen dan karenanya belum dapat diterima secara universal. Namun demikian terdapat konsensus bahwa manajemen menyangkut derajat keterampilan tertentu. Untuk memahami istilah manajemen, pendekatan yang dipergunakan di sini adalah berdasarkan pengalaman manajer. Meskipun pendekatan ini mempunyai keterbatasan, namun hingga kini belum ada perbaikan. Manajemen disini dilihat sebagai suatu sistem yang setiap konponennya menampilkan sesuatu untuk memenuhi kebutuhan. Manajemen merupakan suatu proses sedangkan manajer dikaitkan dengan aspek organisasi (orang - stuktur - tugas - teknologi) dan bagaimana mengaitkan aspek yang satu dengan yang 
lain, serta bagaimana mengaturnya sehingga tercapai tujuan sistem.

Dalam proses manajemen terlibat fungsi-fungsi pokok yang ditampilkan oleh seorang manajer/pimpinan, yaitu: perencanaan (planing), pengorganisasian (organizing), pemimpin (leading), dan pengawasan (controlling). Oleh karena itu, manajemen diartikan sebagai proses merencana, mengorganisasi, memimpin dan mengendalikan upaya organisasi dengan segala aspeknya agar tujuan organisasi tercapai secara efektif dan efesien.

Fungsi perencanaan antara lain menentukan tujuan atau kerangka tindakan yang diperlukan untuk pencapaian tujuan tertentu. Ini dilakukan dengan mengkaji kekuatan dan kelemahan organisasi, menentukan kesempatan dan ancaman, menentukan strategi, kebijakan, taktik dan program. Semua itu dilakukan berdasarkan proses pengambilan keputusan secara ilmiah. Fungsi pengorganisasian meliputi penentuan fungsi, hubungan dan struktur. Fungsi berupa tugas-tugas yang dibagi kedalam fungsi garis, staf, dan fungsional. Hubungan terdiri atas tanggung jawab dan wewenang. Sedangkan strukturnya dapat horizontal dan vertikal. Semuanya itu memperlancar alokasi sumber daya dengan kombinasi yang tepat untuk mengimplementasikan rencana. Fungsi pemimpin menggambarkan bagaimana manajer mengarahkan dan mempengaruhi para bawahan, bagaimana orang lain melaksanakan tugas esensial dengan menciptakan suasana yang menyenangkan untuk bekerja sama. Fungsi pengawasan meliputi penentuan standar, supervisi, dan mengukur penampilan/pelaksanaan terhadap standar dan memberikan keyakinan bahwa tujuan organisasi tercapai. Pengawasan sangat erat kaitanya dengan perencanaan, karena melalui pengawasan dapat diukur dan terukur.

\subsection{Pandangan Tentang Pendidikan}

Walaupun telah sama-sama mengarah pada suatu tujuan tertentu, para ahli masih belum seragam dalam mendifinisikan istilah pendidikan. Driyakarana (1980) mengatakan bahwa pendidikan itu adalah memanusiakan manusia muda. Pengangkatan manusia muda ketaraf mendidik. Dalam Dictionary of Education dinyatakan bahwa pendidikan adalah: (a) proses seseorang mengembangkan kemampuan, sikap, dan tingkah laku lainnya didalam masyarakat tempat mereka hidup, (b) proses sosial yang terjadi pada orang yang dihadapkan pada pengaruh lingkungan yang terpilih dan terkontrol (khususnya yang datang dari sekolah), sehingga mereka dapat memperoleh perkembangan kemampuan sosial dan kemampuan individu optimal.

Dengan kata lain pendidikan dipengaruhi oleh lingkungan atas individu untuk menghasilkan perubahanperubahan yang sifatnya permanen (tetap) dalam tingkah laku, pikiran dan sikapnya. Pengertian lain dikemukakan oleh Crow and Crow (1960); modern ecucational 
theory and practise not only are aimed at preparation for future living but also are operative in determining teh patern of present, day-by-day attitude and behavior.pendidikan tidak hanya dipandang sebagai sarana untuk mempersiapkan hidup yang akan datang, tetapi juga untuk kehidupan sekarang yang dialami individu dalam perkembangan menuju ke tingkat kedewasaanya. Berdasarkan pengertian tersebut dapat didifinisikan beberapa ciri pendidikan, antara lain, yaitu:

a. Pendidikan mengandung tujuan, yaitu kemampuan untuk bekerbang sehingga bermanfaat untuk kepentingan hidup.

b. Untuk mencapai tujuan itu, pendidikan melakukan usaha yang terencana dalam memilih isi (materi), strategi dan teknik penilaianya yang sesuai.

c. Kegiatan pendidikan dilakukan dalam lingkungan keluarga, sekolah, dan masyarakat (formal dan non formal).

\subsection{Manajemen Pendidikan}

\section{Kerangka Kosep dasar Manajemen Pendidikan}

Shrode Dan Voich (1986), menyatakan bahwa kerangka dasar manajemen meliputi: "philosophy, Asumtion, Principles, and theory, which are basic to the study of any discipline of management". Secara sederhana dikatakan bahwa falsafah merupakan pandangan hidup ata persepsi tentang kebenaran yang dikembangkan dari berfikir praktis. Bahwa seorang manajer falsafah merupakan cara berfikir yang telah terkondisikan dengan lingkungan, perangkat organisasi, nilai-nilai dan keyakinan yang mendasari tanggung jawab seorang manajer. Falsafah seorang manajer dijadikan dasar untuk membuat asumsi-asumsi tentang lingkungan, peran organisasinya, dan dari asumsi ini lahir prisnsip-prinsi yang dihubungkan dengan kerangka atau garis besar untuk bertindak. Seperangkat prinsip yang berkaitan antara satu dengan yang lain dikembangkan dan diuji dengan pengalaman sebelum menjadi suatu teori. Untuk seorang manajer, suatu teori tengtang manajemen sangat berfungsi dalam memecahkan masalah-masalah yang timbul.oleh karena itu, falsafah, asumsi, prinsip-prinsip, dan teori tentang manajemen merupakan landasan manajerial yang harus dipahami dan dihayati oleh manajer. Keterkaitan cara pandang tentang manajemen, falsafah, asumsi, dan prinsip, serta teori-teori dijadikan dasar kegiatan manajerial.

\section{Esensi Falsafah Manajemen}

Setiap jenis pengetahuan termasuk pengetahuan manajemen mempunyai ciriciri yang spesifik mengenaai apa (ontologi), bagaimana (epistemologi) dan untuk apa (aksiologi) pengetahuan manajemen disusun. Ketiganya berkaitan satu sama lain (sistem). Ontologi ilmu berkaitan dengan epistemologi, dan epistemologi terkait dengan aksiologi dan seterusnya, tidak bisa terpisah dan harus saling terkait dan mendukung sebagai dasar. Berdasarkan landasan ontologi dan 
aksiologi itu, maka bagaimana mengembangkan landasan epistemologi yang sesuai. Persoalan utama yang dihadapi oleh setiap epistemologi pada dasarnya bagaimana mendapatkan pengentahuan yang benar dengan memperhitungkan aspek ontologi dan aksiologi.

Demikian juga halnya dengan masalah yang dihadapi epistemologi, yakni bagaimana menyusun pengetahuan yang benar untuk menjadi masalah mengenai dunia empiris yang akan digunakan sebagai alat untuk meramalkan dan mengendalikan peristiwa atau gejala yang muncul. Di dalam pengetahuan manajemen, falsafah pada hakikatnya menyediakan seperangkat pengetahuan ( $a$ body of related knowledge) untuk berfikir efektif dalam memecahkan masalahmasalah majemen. Ini merupakan hakikat manajemen sebagai suatu disiplin ilmu dalam mengatasi masalah organisasi berdasarkan pendekatan yang intelegen.bagi seorang manajer perlu pengetahuan tentang kebenaran manajemen, asumsi yang diakui, dan nilai-nilai yang telah ditentukan. Pada akhirnya semua itu akan memberikan kepuasan dalam melakukan pendekatan yang sitematik dalam praktek manajerial.

\section{Sumber Daya Pendidik}

Banyak sumber daya manajemen yang terlibat dalam organisai atau lembaga-lembaga termasuk lembaga pendidik, antara lain: manusia, sarana dan prasarana, biaya, teknologi, dan informasi. Namun demikian sumber daya yang paling penting dalam pendidikan adalah sumber daya manusia. Bagaimana manajer menyediakan menyediakan tenaga, bakat kreatifitas dan semngat bagi organisasi. Karena itu tugas terpenting dari seorang manajer adalah menyeleksi, menempatkan, melatih dan mengembangkan sumber daya manusia, persoalan pengembangan sumber daya manusia mempunyai hubungan yang positif dengan produktifitas dan pertumbuhan organisasi, kepuasan kerja, kekuatan dan profesionalitas manajer.

Yang dimaksut dengan sumber daya manusia, menurut shetty dan venon B. Bucher (1985) terkandung aspek: kopetensi, ketrampilan/skill, kemampuan,sikap perilaku, motivasi, dan komitmen. Dalam pendidikan, jenis sumber daya berdasarkan ruang lingkup keterlibatanya ke dalam penyelenggaraan pendidikan dikelompokkan ke dalam SDM pendidikan dalam sekolah dan SDM pendidikan luar sekolah. Apabila dilihat dari segi tugas pokoknya, dibedakan menurut tenaga teknis, tenaga administrasi dan tenaga penunjang. Selanjutnya dalam PP 38/ 1992 tentang tenaga kependidikan ditegaskan pengelompokannya menjadi tenaga pendidik, (pembimbing, pengajar, pelatihan) pengelola, pengawas, laboran, teknisi sumber belajar, peneliti dan penguji.

Persoalan pokok dalam pembinaan tenaga kependidikan adalah pembinaan etos kerja. Etos kerja adalah sikap mental untuk menghasilkan produk kerja yang baik, etos kerja adalah sikap 
mental untuk menghasilkan produk kerja yang baik, bermutu tinggi baik barang maupun jasa. Menurut Mochtar Buchari (kompas, 17 April 1993) etos kerja dipengaruhi oleh variabel sikap, pandangan, cara-cara, dan kebiasaankebiasaan kerja yang ada pada seseorang, suatu kelompok, atau bangsa. Pembinaan etos kerja ini merupakan bagian dari pembinaan tata nilai (value system), dan dalam dunia pendidikan masalah ini tidak cukup diperhatikan. Pada pengembangan mutu SDM ini yang paling banyak dilakukan pembinaan keterampilan untuk melakukan sesuatu yang nyata seperti keterampilan untuk melakukan sesuatu yang nyata seperti keterampilan komputer, menjahit, akuntansi, dan sebagainya. Akan tetapi membentuk keinginan bagaimana melakukan pekerjaan-pekerjaan itu sebaik-baiknya kurang diperhatikan. Tentunya hal ini hanya dapat terwujud jika kemampuan menghasilkan sesuatu yang bermutu itu diyunjang oleh etos kerja, motivasi tinggi untuk berprestasi. Bagaiman caranya memumpuk etos kerja. Salah satu usaha dengan menciptakan suasana kerja yang mengantarkan perilaku karyawan/guru ke arah yang lebih produktif secara langsung mengubah sikap, pandangan harapan dan keterampilan/ keahlian yang lebih efektif yang sekarang sudah tidak sesuai dengan tuntutan perkembangan zaman.

\subsection{Pengertian Manajemen Pendidikan Berorientasi Masa Depan}

Manajemen pendidikan

merupakan suatu proses yang merupakan daur (siklus) penyelenggaraan pendidikan yang dimulai dari perencanaan, diikuti oleh pengorganisasian, pengarahan, pelaksanaan, pemantauan dan penilaian tentang usaha sekolah untuk mencapai tujuannya (Suryosubroto, 2004: 27). Selain itu manajemen pendidikan juga didefinisikan sebagai suatu kegiatan atau rangkaian kegiatan yang berupa proses pengelolaan usaha kerjasama sekelompok manusia yang tergabung dalam organisasi pendidikan, untuk mencapai tujuan pendidikan yang telah ditetapkan sebelumnya, agar efektif dan efisien (Suharsimi Arikunto \& Lia Yuliana, 2008: 14). Dari dua pandangan tentang manajemen pendidikan, dapat disimpulkan bahwa manajemen pendidikan merupakan suatu kegiatan atau rangkaian kegiatan yang merupakan daur (siklus) penyelenggaraan pendidikan untuk mencapai tujuan pendidikan yang telah ditetapkan sebelumnya agar efektif dan efisien.

Masa depan merupakan zaman yang akan datang atau belum terjadi (Poerwadarminta, 1984: 634). Masa depan pendidikan perlu diperhatikan oleh para pendidik. Dimasa yang akan datang, telah terpampang cita-cita dan harapan dari suatu pendidikan. Cita-cita dan harapan pendidikan dapat terwujud jika sudah ada gambaran yang ada dimasa yang akan datang.

Dari pengertian-pengertian diatas dapat ditarik kesimpulan bahwa manajemen pendidikan dimasa depan merupakan manajemen pendidikan yang dirancang atau disusun untuk menghadapi 
tantangan masa depan. Manajemen pendidikan mempunyai fungsi yang harus dipahami oleh para manajer pendidikan masa depan. Fungsi tersebut antara lain: perencanaan, pengorganisasian, pengarahan, dan pengkoordinasian. Perencanaan pendidikan merupakan suatu proses mempersiapkan serangkaian keputusan untuk mengambil tindakan pendidikan dimasa depan yang diarahkan kepada tercapainya tujuan-tujuan dengan sarana yang optimal. Pengorganisasian pendidikan merupakan usaha bersama oleh sekelompok orang untuk mencapai tujuan pendidikan yang telah ditetapkan sebelumnya, dengan mendayagunakan sumber-sumber yang ada agar dicapai hasil yang efektif dan efisien. Pengarahan pendidikan merupakan suatu usaha yang dilakukan oleh pimpinan pendidikan untuk memberikan penjelasan pendidikan, serta bimbingan kepada para orang-orang yang ada dibawahnya sebelum dan selama melaksanakan tugas. Pengkoordinasian dalam pendidikan merupakan suatu usaha yang dilakukan pimpinan untuk mengatur, menyatukan, menyerasikan, mengintegrasikan semua kegiatan yang dilakukan bawahannya dalam dunia pendidikan.

Hal yang harus direncanakan pada penyusunan manajemen pendidikan adalah hasil yang ingin dicapai dari pendidikan dan bagaimana kegiatan pendidikan tersebut dapat berjalan dengan lancar tanpa adanya halangan suatu apapun. Yang sangat penting adalah korelasi antara proses dan hasil dari pendidikan tersebut.

\subsection{Alasan Penyusunan Manajemen Pendidikan Berorientasi Masa depan}

Manajemen pendidikan disusun untuk menghadapi tantangan pendidikan dimasa depan. Dalam hal ini manager pendidikan atau gurulah yang mendapatkan tantangan tersebut. Tantangan guru dimasa depan bangsa, antara lain untuk menghadapi: era globalisasi, era informasi, era IPTEK, dan era perubahan cepat.Guru dan dosen sebagai manajer pendidikan harus selalu siap menghadapi tantangan tersebut. Salah satunya adalah dengan menyusun serta merencanakan manajemen dimasa depan. Hal ini perlu dilakukan guna meningkatkan mutu pendidikan yang ada.

Pemimpin masa depan adalah pemimpin yang siap menghadapi tantangan pendidikan dimasa depan. Yang menjadi pemimpin masa depan adalah diri kita sendiri. Kita harus siap menjadi seorang pemimpin dimasa depan. Setiap orang berkompetensi untuk menjadi seorang pemimpin. Untuk menjadi seorang pemimpin harus mempunyai bekal yang banyak. Bekal tersebut berupa cara membuat manajemen yang bagus, mempunyai jiwa kepemimpinan, wawasan yang luas, serta mempunyai hubungan sosial yang baik.

\subsection{Pelaksanaan Manajemen Pendidikan Masa depan}

Pelaksanaan

manajemen pendidikan harus dimulai dari sekarang. Istilah penundaan pelaksanaan haruslah dihilangkan. Kita sebagai calon pemimpin masa depan harus melaksanakan 
manajemen pendidikan dimasa depan dari sedini mungkin.

\section{Tempat Pelaksanaan Manajemen Pendidikan}

Tempat pelaksanaan manajemen pendidikan dimasa depan adalah ditempat yang kita pijak saat ini. Kita bekerja di instansi pendidikan yaitu di perguruan Tinggi. Kita harus melaksanakan pendidikan tersebut dimana kita mengajar.

\section{Cara Menyusun Manajemen} Pendidikan Dimasa Depan

Penyusunan manajemen

pendidikan di masa depan harus memperhatikan: 1) intake, 2) proses, 3) instrumental input, 4) environmental input, 5) out put, 6) out come. Intake dalam hal ini adalah siswa atau peserta didik. Intake dapat dilihat sejak adanya kegiatan penerimaan murid baru. Pengadaan murid baru dilaksanakan dengan seleksi murid. Seleksi murid tidak berdasarkan martabat serta status ekonomi siswa, tetapi berdasarkan kriteria umur. Dalam hal ini, juga harus menetapkan kapasitas atau jumlah calon yang diterima. Pengumuman hasil seleksi dibuat sedemikian rupa sehingga bisa diketahui oleh masyarakat luas.

Karakteristik dari intake harus diperhatikan. Intake yang ada diselidiki keadaannya, baik dari segi ekonomi keluarga, rata-rata pendidikan di keluarga, gaya hidup keuarga, serta persepsi keluarga terhadap pendidikan. Hal ini perlu dilaksanakan agar supaya intake dapat diproses dengan mudah. Suatu proses pendidikan dipengaruhi oleh dua factor, yaitu factor instrumental input dan factor environmental input. Factor instrumental input mencakup beberapa unsur penting, diantaranya adalah peserta didik, pendidik, kurikulum, manajemen, sarana dan prasarana, serta stake holder atau komponen pendukung. Unsur peserta didik harus disusun manajemennya dengan sebaik mungkin. Peserta didik dimanage sesuai dengan taksonomi perkembangan anak, yang mencakup: ranah kognitif, afektif, dan psikomotor.

Kurikulum merupakan suatu program pendidikan. Di dalam kurikulum terdapat organisasi kurikulum. Organisasi kurikulum merupakan pola atau bentuk penyusunan bahan pelajaran yang akan disampaikan pada murid-muridnya. Kurikulum di Indonesia sebenarnya sudah bagus, baik segi materi, serta tujuan yang ingin dicapai. Hanya saja pelaksana dari kurikulum yang masih belum bisa menanggapinya dengan baik. Sebagai calon pemimpin masa depan, sebaiknya kita dapat melaksanakan kurikulum yang ada dengan bagus dan syukur dengan menambahkan apa yang masih kurang pada kurikulum, dan membuang unsur yang sia-sia atau muspro.

Pendidik merupakan faktor penentu berhasil atau tidaknya suatu proses pendidikan. Me-manage pendidik bukanlah hal yang mudah. Hal ini diakibatkan setiap pribadi mempunyai perbedaan. Me-manage pendidikan dimulai dari diri sendiri. Hal-hal yang belum dilaksanakan dalam pendidikan adalah meningkatkan kualitas pendidik dengan membuang hal-hal yang masih 
dianggap sia-sia. Sarana dan prasarana serta komponen pendukung harus diperhatikan dengan jeli. dan prasarana yang belum ada dilengkapi dengan meminta bantan baik kepada pemerintah maupun kepada masyarakat sekitar.

Factor environmental input pendidikan merupakan faktor yang mempengaruhi proses pendidikan. Faktor environmental merupakan faktor yang berasal dari luar. Faktor itu berupa lingkungan rumah siswa maupun lingkungan sekolah siswa. Proses pendidikan yang dipengaruhi oleh instrumental input dan environmental input yang bagus akan mempengaruhi output dari pendidikan. Dari output tersebut akan mempengaruhi outcome. Sebagai seorang manajer pendidikan dimasa depan kita harus memperhatikan hal-hal tersebut.

\section{PENUTUP}

\subsection{Kesimpulan}

Manajemen pendidikan dimasa depan merupakan manajemen pendidikan yang dirancang atau disusun untuk menghadapi tantangan masa depan. Manajemen pendidikan mempunyai fungsi yang harus dipahami oleh para manajer pendidikan masa depan.

Persoalan pokok dalam pembinaan tenaga kependidikan dalam memnghadapi masa depan adalah pembinaan etos kerja. Etos kerja adalah sikap mental untuk menghasilkan produk kerja yang baik, etos kerja adalah sikap mental untuk menghasilkan produk kerja yang baik, bermutu tinggi baik barang maupun jasa.

Falsafah seorang manajer dijadikan dasar untuk membuat asumsiasumsi tentang lingkungan, peran organisasinya, dan dari asumsi ini lahir prisnsip-prinsi yang dihubungkan dengan kerangka atau garis besar untuk bertindak. Seperangkat prinsip yang berkaitan antara satu dengan yang lain dikembangkan dan diuji dengan pengalaman sebelum menjadi suatu teori. Untuk seorang manajer, suatu teori tengtang manajemen sangat berfungsi dalam memecahkan masalah-masalah yang timbul.oleh karena itu, falsafah, asumsi, prinsip-prinsip, dan teori tentang manajemen merupakan landasan manajerial yang harus dipahami dan dihayati oleh manajer.

Perencanaan dalam penyusunan manajemen pendidikan adalah hasil yang ingin dicapai dari pendidikan dan bagaimana kegiatan pendidikan tersebut dapat berjalan dengan lancar tanpa adanya halangan suatu apapun. Yang sangat penting adalah korelasi antara proses dan hasil dari pendidikan tersebut.

1. Manajemen pendidikan merupakan suatu kegiatan atau rangkaian kegiatan yang merupakan daur (siklus) penyelenggaraan pendidikan untuk mencapai tujuan pendidikan yang telah ditetapkan sebelumnya agar efektif dan efisien.

2. Manajemen pendidikan disusun agar pendidikan yang ada dapat 
bersaing dengan tantangan pendidikan masa depan.

3. Pemimpin masa depan adalah diri kita sendiri.

4. Pelaksanaan manajemen pendidikan dimulai dari sekarang.

5. Manajemen pendidikan dilaksanakan di tempat kita mengajar

6. Cara menyusun manajemen pendidikan harus memperhatikan: a. Intake, b. Proses, c. Instrumental input, $d$. Environmental input, e. Out put, $f$. Out come.

\subsection{Saran}

1. Para pendidik sebaiknya menyiapkan manajemen dimasa depan agar dapat bersaing dengan tantangan pendidikan masa depan.

2. Pelaksanaan manajemen sebaiknya praktis dan efisien.

3. Pelaksanaan manajemen yang siasia sebaiknya ditinggalkan saja.

4. Nilai relewansi sesuai dengan kondisi dan kebutuhan terkini yang menjadi dasar penerapan manajemen.

\section{DAFTAR PUSTAKA}

Boediono, (1994). Pendidikan dan Latihan Dalam Periode Tinggal Landas. Mimbar Pendidikan, No. 1 Tahun XIII.

Crown, LD, Crow, (1960), A Introduction to Education, New York: American Book Coy.
Dertouzas, M.L., Lester, R.K., dan Solow, R.M., (1989). Made In America: Regaining the Productive Edge. Cambridge, MA: Harper Perennial.

Driyarkara (1980), Tentang Pendidikan, Jakarta: Yayasan Kanisius.

Gilley, J.W., dan Eggland, S.E.,(1989). Principles of Human Resource Development. Reading, MA: Addison-Wisley Publishing Company, Inc.

Jones, J dan Walter, L. Donald, (2008). Human Resource Management in Education. Manajemen Sumberdaya Manusia dalam Pendidikan. Yogyakarta: $Q-$ Media,

Koontz Haraold, Cyril O’Donnel, Heins W.,(1982), Esensial of Management, New Delhi: Tate McGraw Hill Publishing Company.

Megginson, D., Joy-Mattews, J., dan Banfield, P., (1993). Human Resource Development. London: Kogan-Page Limited.

Simanjuntak, P., (1985). Pengantar Ekonomi Sumber Daya Manusia. Jakarta: Lembaga Penerbit Fakultas Ekonomi, Universitas Indonesia.

Suryadi, A.(1995). Kebijaksanaan Pendidikan dan Pengembangan Sumberdaya Manusia: Transisi Menuju era Indonesia Modern. Jakarta: Pusat Informatika, Balitbang Dikbud

Shrode A. William, Dan Voich, JR., (1974), Organization and Managemen: basic systems concepts, Malaysia : malaysia by Irwin Book, Company. 